\title{
2. Before the Mission Station: From first encounters to the incorporation of settlers into Indigenous relations of obligation
}

\author{
John M. White
}

\section{Introduction}

By the end of the twentieth century, Aboriginal people of the Eurobodalla region of the NSW South Coast were broadly incorporated into the expanding settler economy. ${ }^{1}$ With ongoing labour shortages impeding economic development, Aboriginal labour became critical to the success of the forestry and fishing industries and to the emergence of seasonal horticultural industries. Shortfalls in income were supplemented with the continuance of subsistence fishing. These patterns of seasonal employment were characteristic of the hybrid economy of the Eurobodalla until the 1970s (see White 2010, 2011). Altman (2001) employs the hybrid economy model to counter perspectives on the marginalisation of Aboriginal people from the settler-capitalist (or 'real') economy. His model comprises the intersection of customary, market and state sectors of economic activity. Altman applies this concept to contemporary Aboriginal communities in remote northern Australia. As Keen (2010:8) notes, however, the model is 'readily adaptable to capture the variety of local economies that emerged on the frontier'. ${ }^{2}$ On the southern NSW coastal frontier, local Aboriginal people were forced off their country by the expansion of small-scale landholdings, and subsequently moved variously between estuarine camps close to sources of employment and the government-administered station at Wallaga Lake. Rather than examining the processes of incorporation into the settler economy, this chapter aims to invert the question and will explore how Aboriginal people came to incorporate the presence of settlers into pre-existing, seasonal and dynamic patterns of economy and sociality. In doing so, this chapter will wind the clock back to a critical juncture in the region's history of intercultural

\footnotetext{
1 This chapter is indebted to the Eurobodalla Aboriginal Cultural Heritage Study steering committee and to the excellent research conducted by Goulding and Waters (2005) in compiling an Aboriginal history of the Eurobodalla.

2 Elsewhere (White 2011), I have problematised the application of Altman's model to past-focused studies and have suggested that the nature of exclusion, social control and exploitation also needs to be taken into account when discussing the articulation between customary and settler modes of production.
} 
relations: the initial four decades of contact that resulted in Aboriginal groups moving from social and spatial distance to incorporating settlers into relations of obligation. Through an examination of the documentary record, the chapter also suggests that the Eurobodalla experienced a highly localised process of European colonisation.

The recent edited volume by Jolly et al. (2009) provides interesting points of comparison regarding early or initial intercultural encounters in the Pacific that encompassed both extreme violence and exchange. In Papua New Guinea, several writers have discussed emergent relationships with Australian patrols (Bonnemère and Lemonnier 2009; Strathern 1992). Marilyn Strathern (1992) described the exchange of shells in the Mount Hagen region as part of a revelatory moment in which the distinction between Hageners and the Australian strangers was collapsed. Strathern argues that 'above all, they were recognisable as human because they contained within them the capacity to transact' (Strathern 1992:251). In Australia, there is a considerable body of literature dealing with general themes of massacre, theft and reprisals in the initial encounters between settlers and Aboriginal people in a variety of spatial and temporal locations. For example, in analysing depictions of Aboriginal people in violent conflicts on the Macleay River pastoral runs, Barry Morris gave legitimacy to Taussig's term 'the culture of terror' (Taussig 1987). Elsewhere in New South Wales (and more generally throughout Australia), conflict on the pastoral frontier was an ongoing concern for the colonial administration (see Loos 1982; Reece 1974; Reynolds 1981; Robinson and York 1977). ${ }^{3}$ Literature dealing with congeniality or exchange in the initial encounters between Aboriginal people, explorers and settlers is sparse, although there are several accounts of Europeans being saved from starvation when they were lost in the bush (see Flannery and Morgan 2002; Morrill 2006). Henry Reynolds provides a range of Aboriginal 'first encounters' with Europeans (as well as with introduced animals and new material goods), and considers how Aboriginal people attempted to 'explain the newcomers in traditional terms and to assimilate them within kinship networks' (Reynolds 1981:3).

In view of the available archival material on the Eurobodalla region, this chapter will argue that the most compelling reason for the rapid tempering of intercultural violence, theft and reprisals, and the rapid incorporation of Aboriginal labour in the emerging settler economy, is the relationship between exchange and relatedness. In approaching the concepts of exchange and relatedness, I am following Strathern's example of the Mount Hagen encounter insofar as the human/non-human binary was collapsed by the Anglo-Australians' ability to exchange culturally meaningful shells. As Strathern noted, 'this gave them a

3 Prevailing accounts of violence in the Australian context reflect the specific mode of production in the dominant pastoral sector of the settler economy. The forcible alienation of Aboriginal people from their country was both a question of economic viability and a question of survival. 
dimension in time. Or to put it another way, this made relationship possible' (Strathern 1992:249). I suggest that it is precisely the breakdown of these self/ other binaries that is required if we are to approach the inverted question of socioeconomic incorporation. In this chapter, I am using the notion of relatedness as a flexible category rather than as a bounded polity defined by kin relations. Myer's (1986) conceptualisation of relatedness (as opposed to 'differentiation') is instructive in this respect. In a structural-functionalist, 'bubble' notion of culture (described by Redmond as the 'culture gardens' approach), relatedness is rigidly dialectical to differentiation and tends to obfuscate the range of interactions and identifications in an intercultural context (Redmond 2005:234). I argue here that Yuin relations with non-kin co-residents (settlers) cannot be viewed in terms of 'either' or 'or', but rather as being incorporated into a relatively open sociality not necessarily defined in terms of kin relations. Following Strathern, I argue that exchange between individuals gave Europeans a tangible, temporal dimension for the Yuin.

\section{Early History of Intercultural Relations}

William Drew's reflections on the early days of the European colony at Sydney'the first seeds of which were sown amid the sighs and groans and tears of the wicked and worthless, and the swish of the dreadful cat and the clank of iron gyves' - provide an important insight into the shaping of colonial subjectivities through violence and suffering (Sergeant William Drew in Becke and Jeffery 1896:140). Referring to the lashing of several convicts, Drew describes the 'spectacle' as 'a very dreadful one', and remarks that he would 'never forget the feeling of horror' that he 'experienced in witnessing their punishment' ( $\mathrm{p}$. 70). Following the arrival of the First Fleet in Sydney, Drew observed several encounters between Aboriginal people and Europeans and concluded: 'there is no doubt in my mind the savages of this country are a treacherous race' of 'murderous inclinations' (p. 128). This is perhaps what Taussig refers to as 'the reciprocating yet distorted mimesis' of the 'colonial mirror which reflects back onto the colonists the barbarity of their own social relations, but as imputed to the savage or evil figures they wish to colonise' (Taussig 2002:9). ${ }^{4}$ The fear of Aboriginal people precipitated certain kinds of interactions in the dialectic described by Taussig (2002) as a 'culture of terror'. Taussig urges that

we would be most unwise to overlook or under-estimate the role of terror.

And by this I mean us to think through terror, which as well as being a

\footnotetext{
4 This is also reminiscent of the kind of dichotomous order posited by post-colonial theorists such as Franz Fanon (1970) and Homi Bhabha (1993), in which the colonised (to borrow the phrase from Biber) become the 'dark doppelgänger of their new imperial masters' (Biber 2005:623).
} 
physiological state is also a social fact and a cultural construction whose baroque dimensions allow it to serve as the mediator par excellence of colonial hegemony. (Taussig 2002:1)

These 'baroque dimensions' of terror are explicit in the late eighteenth and early nineteenth-century rumours that Aboriginal people south of Botany Bay were 'hostile savages' and 'were generally believed to be cannibals' (Bowden 1952:37). This image was later distributed in Maclehose's (1838) Picture of Sydney and Stranger's Guide in New South Wales for 1838, which sought to inform new arrivals to the colony of the barbarous practices of Aboriginal people, including the widespread phenomenon of cannibalistic infanticide amongst Aboriginal men. The Sydney Herald was also complicit in promulgating the image of savagery and cannibalism during the late 1830s (see Reece 1974:93). In her discussion of cannibalism in Australian colonial discourse, Biber (2005) draws on the 1826 case of a shepherd, Henry Preston, who became lost near Wollondilly (on the southern outskirts of the colony at Sydney). Allegations of cannibalism were laid against several Aboriginal people in the district and were reported to Governor Ralph Darling. A few days later, 'Preston walked out of the bush unharmed' (Biber 2005:622).

Pickering's research into the available archival sources on cannibalism in Australia led him to the conclusion that 'there is no reliable evidence to support the claim that Australian Aboriginal societies practiced institutionalised cannibalism' (Pickering 1999:51). In retrospect, however, Pickering's findings would have provided little comfort to the European settlers at Wollondilly. In the case of Henry Preston, the allegation of cannibalism was a product of a historical moment of mythologised characterisation. As Biber remarks, this kind of 'cannibal discourse is the product of colonial anxiety', the origins of which 'lay in childhood fantasies of cannibalistic savages roaming the darkest corners of the Empire' (Biber 2005:629). ${ }^{5}$ On a localised level, terror as a social fact existed in a dialectic that created, and was created by, mediated narratives of violence beyond Sydney and the Cumberland Plain that served to fashion a phantasmic image of South Coast Aboriginal people in the 'space of death'. By projecting the image of terror onto Aboriginal people (Taussig's 'victims'), Europeans could rationalise their own acts of violence. Further, in the 'epistemic murk' of these mediated narratives documenting atrocities committed by Aboriginal people, the actions of soldiers, sealers, sailors and settlers were motivated, retold and reconstituted.

Documentary records suggest that Europeans and Aboriginal people initially came into physical contact in the Eurobodalla region of New South Wales in 1797. A ship, the Sydney Cove, foundered on a beach at Gippsland and the crew

5 For a more general analysis of these types of discourses, see Lindenbaum (2004). 
began the long journey by foot up the coast to the colony at Sydney. Of the 17 men who survived the wreck, only four made it back to Sydney, encountering several 'hostile' groups of Aboriginal people along the way (Goulding and Waters 2005:24). One of the survivors, W. Clarke, recalled meeting with Aboriginal people in the vicinity of the Tuross River estuary:

Met fourteen natives who conducted us to their miserable abodes in the wood adjoining to a large lagoon and kindly treated us with mussels, for which unexpected civility, we made them some presents. These people seem better acquainted with the laws of hospitality than any of their countrymen...for to their benevolent treat was added an invitation to remain with them for the night...As far as we could understand these natives were of a different tribe from those we had seen and were then at war with them. They possessed a liberality to which the others were strangers and freely gave us a part of the little they had. (Clarke, cited in Gibbney 1989:14)

Provisioning of this type is not without precedent, as the famous accounts of James Morrill and William Buckley suggest. Aboriginal people saved Morrill from starvation after he was shipwrecked off the Great Barrier Reef in the 1840s and he continued to live in camp for nearly two decades (Morrill 2006). Similarly, Buckley, an escaped convict, was given food in his initial encounter with Wautharong people and continued to live and travel with them for many years (Flannery and Morgan 2002).

Following Clarke's encounter, there is no documentary evidence of interactions between Europeans and Aboriginal people in the Eurobodalla region until 1806. Wesson, however, identified that a woman of mixed descent was reported to be living in the Bodalla area in 1842 and approximates the year of her birth as 1804. This date, Wesson argues, predated both the arrival of the first pastoralists and the advent of onshore whaling at Twofold Bay (Wesson 2002:18). Although there is little documentary evidence of their activities, sealers were clearly travelling along the South Coast by the end of the eighteenth century. As Wesson suggests, sealers were probably illiterate and would have had little reason to document their activities (Wesson 2002). As Amery and Muhlhausler further noted, 'many of the sealers were runaway convicts and sailors who had left their ships in Sydney' (Amery and Muhlhausler 1996:48). It appears that the practice of abducting Aboriginal women was also common among sealers. Captain Kelly wrote in 1815 that it was 'customary' for sealers based in Bass Strait to 'have from two to five of those native women for their own use and benefit' (Henley and Plomley 1990). Kelly also refers to adult children of mixed descent, which again places the sealers on the south-eastern coastline prior to 1806. In March 1806, Governor Philip King reported that a number of Aboriginal people had been killed by sealers at Twofold Bay (Governor King, cited in Organ 1990:30). 
Two later articles appeared in the Sydney Gazette referring to the terror experienced by European seamen encountering Aboriginal people at Batemans Bay (Sydney Gazette, 15 May 1808, 26 May 1821). The second account, in 1821, provides macabre details of the events and is consistent with the reporting style of the era:

The next morning (Easter Sunday) at daylight, they were suddenly attacked by about twelve natives, with a discharge of 50 or 60 spears, followed up by a continued volley of stones. James Brock was thrice speared; one entered a thigh, another slightly grazed his breast, and the third perforated the chest; which produced instantaneous death...The unfortunate men were now in a truly pitiable and forlorn condition; Block was lying in the boat a corpse; Whittaker was sorely wounded; and Thorn beheld nothing but a horrid and cruel death, at the hands of the savages, ready to meet him, or else the dread expectancy of being entombed in the ocean's vast abyss. (Sydney Gazette, 26 May 1821:3)

By way of the prominence of the two articles in Australia's first newspaper, the reputation of the ferocity of Aboriginal people at Batemans Bay was broadly circulated in Sydney, reinforcing rumours of terror and cannibalism in the south.

The 1821 voyage of the Snapper encountered Aboriginal people as it entered Batemans Bay and explored the Clyde River. The leader of the exploratory party, Lieutenant Robert Johnson, reported to the Sydney Gazette that '[a]t one Place I landed, taking with me the two Natives who accompanied me from Sydney, upon which we were met by a Tribe of them, who shewed [sic] no Symptoms of Hostility towards us, but entered freely into Conversation' (Sydney Gazette, 10 December 1821:1).

Johnson was able to gain information about the loss of another ship further south in which Captain Stewart's group of survivors was 'cut off by the Natives of Two-fold Bay', and of an escaped convict who had, it was asserted, capsized his boat in the middle of Batemans Bay and had not made it to shore (Sydney Gazette, 10 December 1821:1). Johnson concluded that the convict, Briggs, and his companions had 'suffered the same fate' as the shipwrecked party at Twofold Bay. While Johnson had personally experienced no hostility from Aboriginal people at Batemans Bay, his report still emphasised the perils of southward journeys, and it was assumed that the attack was motivated by cannibalism (Reece 1974:102). Once again, the image of terror on the southern maritime frontier was circulated in Sydney by the Gazette. The following year, 1822, a member of Charles Throsby's overland exploration party ventured towards Batemans Bay but lost his nerve 'because of the reputed hostility of the natives in this area' (Perry 1963:100). 
Four years later a Wesleyan missionary led an expedition to the South Coast in the hope of finding a suitable location to base a mission. In October 1826, John Harper arrived at Batemans Bay and for the next two weeks encountered, without hostility, a number of Aboriginal people in the area who, in his words, had not been 'contaminated by the whites' (Harper 1826). Importantly, Harper initiated contact by offering an Aboriginal man blankets and biscuits, which were reciprocated with 'several presents' once he was led to shore (Harper 1826). Harper clearly believed that friendly relationships could be forged with Aboriginal people as long as Europeans acted with integrity:

No man of pure motives need be afraid of travelling with the blacks, even in the most obscure place. Alltho' [sic] this assertion is not credited in the Colony by some people, yet I know from experience more than thousands who would object to it...Let the whites reform their conduct and they need never be afraid. (Harper 1826)

The Wesleyan Missionary Society, of which Harper was a leading figure in the new colony, held the view that their ministries (their 'saving plan of redemption') needed to be separate from European settlement, at the 'uttermost bounds of their scattered, uncivilised, unsociable and cannibal tribes' (Walker n.d.). The 'contamination' that Harper refers to in his journal reflected his view that the colony was a place of 'vile infamous and libidinous conduct' (Harper 1827). Harper's mentor, Reverend Walker, also believed that missions would have most success 'at a proper distance from the theatre of temptation' (Walker 1821). While Harper intended to return to Batemans Bay to establish the mission, his request was denied by Governor Darling, who concluded that allowing the selection of land by the Wesleyan Missionary Society 'would have been prejudicial to the interests of the settlers' (Darling 1827). In the same year, the government surveyor, Thomas Florance, was given the task of providing a detailed survey of the coastal region between Jervis Bay and Moruya in 1828. Florance compiled a report on possible regions for settlement, based on the proximity of sheltered ports or potential harbours to land suitable for agricultural production (Dowd 1972). Harper's desire to Christianise Aboriginal people at Batemans Bay, at a distance from the contaminating influence of settler society, paradoxically led to the widespread settlement of the region. His genuine effort to create a mission coupled with his reports of friendly, rather than hostile 'savages' inspired a new confidence in the possibility of settlement in the south. Following Harper's unsuccessful application to Governor Darling, the Eurobodalla region was settled within three years. ${ }^{6}$

6 Gibbney wrote that 'wandering cattlemen had penetrated south of the Bay by about 1826', but does not provide any sources for the claim (Gibbney 1989:18). Presumably, these cattlemen would have originated from the expansion of pastoralism on the Monaro plain during this period and had come down to the coast via the Araluen Valley. 
The first settler at Murramarang, William Morris, wrote a number of letters to the Governor reporting the spearing of cattle and threatening of settlers by Aboriginal people, and requested permission to be given to shoot those responsible and for soldiers to be sent to ensure the settlers' safety (Morris, 24 September 1830, cited in James 2001:5). In response, Lieutenant Macalister was sent to the Batemans Bay area and concluded that Aboriginal people from the mountains (rather than the coastal Yuin) were responsible for the violence. Macalister proposed that the conflict was a result of mountain groups missing out on blankets that were distributed by Morris on behalf of the colonial administration. In response, blankets were distributed evenly to both the mountain people and the coastal Yuin. Macalister's report in 1831 concluded that the incidents were anomalous and that his mediations had settled the matter once and for all (Macalister 1831, cited in Organ 1990:170). Gibbney's account gives credit to Macalister as an 'unusually intelligent officer' for seeking 'pacification not punishment' and that his efforts were so successful that 'even Morris ceased to complain and the Aboriginal people never again attempted resistance' (Gibbney 1989:22). Organ rightly noted, however, that Gibbney's 'account glosses over the more unsavoury aspects of this affair-it does not describe the European atrocities' (Organ 1990:164).

A year after Macalister's report, a shooting party led by Joseph Berrymen murdered two men, a pregnant woman and an older woman at Murramarang. Organ (1990) provides a documentary record of the killings that offers conflicting accounts of the events, ranging from the complainant, Mr Thompson, to the accused, Joseph Berryman. In the end, Berryman escaped without charge. While there is no direct evidence implicating Morris of Murramarang with recruiting the shooting party, Morris was clearly dissatisfied with Macalister's approach to resolving the matter. In both of his letters, Morris calls for permission to be given to shoot the ringleaders as his desired form of reprisal. It is unclear, however, whether or not Morris decided to take the matter into his own hands. By 1845 it appears that, in general, the hostilities had ceased and the prevalence of livestock theft had been ameliorated by Macalister's mediations (Gibbney 1989:21-8; James 2001:7). In the absence of further documented conflicts, it appears that the initial era of intercultural relations had come to an end. Memories of frontier violence remain in the oral history of Aboriginal people on the South Coast today. A prominent narrative implicates one of the first settlers to arrive in the region in the 1840s, Alexander Weatherhead. In various accounts, Weatherhead has been described as deliberately poisoning Aboriginal people through the use of flour or cream laced with strychnine. In other oral testimonies, Weatherhead is also remembered as forcing Aboriginal people to work as slaves when he was serving as manager at Nugatta Station. An unrelated account refers to atrocities being committed in the vicinity of Coila Creek. It is likely that many further incidences of violence occurred but were not documented. 


\section{Exchange, Provisioning and Heroism at Broulee}

The original settlement at Broulee was heavily reliant on provisions shipped from Sydney. In between shipments, the small community of settlers was saved from starvation on several occasions during the 1830s by local Aboriginal people who provided them with seafood (Rose 1923:375). Later, in 1841, a heroic story emerges of Aboriginal people saving the survivors of the shipwrecked Roverat Broulee in a daring rescue operation. With the settlers unable to swim out through the surf, several Aboriginal people risked their own lives to rescue the seamen. Two accounts of the rescue provide conflicting details as to the number of Aboriginal people involved and the mode of rescue. Robinson's second-hand account of the saga gives reference to two men:

I was happy to find that the other Aborigines along the Coast were equally well spoken of several persons by their instrumentality had been saved. The most striking instance (brought under notice) was the Wreck of a Steamer in a Storm at Broole [sic] when all hopes of saving the white persons were given up, and when no Individual would venture, two Aboriginal natives at the imminent risk of their own lives boldly plunged into the Breakers and rescued the sufferers who but for them must have perished. (Robinson 1844, cited in Mackaness 1978:23)

In contrast, an account from 1849 increases the number of rescuers to 15 and details a highly coordinated rescue effort:

Some of the tribe...greatly distinguished themselves, three or four years since, by saving the crew of a schooner which was wrecked in the surf. The white by-standers stood aghas [sic], and could not contrive means to render any assistance; but fifteen of the aborigines formed a line, hand in hand, and went into the surf and saved all on board. (Townsend 1849, cited in Cleary 1993:39)

Regardless of the conflicting details, the actions of the heroes at Broulee are remarkable. But is it enough to view these events, and the earlier provisioning of Clarke's party, as evidence that Yuin people were, as Gibbney suggests, 'clearly a kindly folk who welcomed travelers' (Gibbney 1989:14). The hostility towards seamen on the maritime frontier contradicts that assumption, despite the actions probably being in retaliation to earlier atrocities committed by the marauding sealers.

In his analysis of provisioning in Aboriginal systems, Keen identified that 'people invested in the productivity of others through their own generosity, and expected recipients to be generous in return. Indeed, continuing relatedness required constant affirmation through giving' (Keen 2004:354). Therefore, 
underlying systems of reciprocal giving are a fundamental premise of the existence of relatedness. A. W. Howitt (1904) provided a key early ethnography of the South Coast region, detailing forms of sociality and exchange practices in the late 1800s. Howitt observed that Yuin people were intermarrying and trading with groups from the Shoalhaven in the north, the Braidwood district in the west, and with groups from Twofold Bay and the coastal range in the south. ${ }^{7}$ These transactions included sister exchange and the trade of weapons, food and other goods. Reciprocal giving occurred within a network of relatedness reinforced by cycles of transactions. This framework is useful in examining the provisioning of settlers at Broulee in the 1830s because relationships had already been formed between the first settlers and Aboriginal people. The earliest written record identifying individual Aboriginal workers was provided by John Hawdon, who, along with Francis Flanagan, had taken up land in the Moruya area by 1830. Presumably, Hawdon was exchanging rations for labour and it is clear that he was highly regarded by Aboriginal people in the region, as the following passage suggests: 'They always regarded Mr. Hawdon's word as law, and he was called upon to settle many a dispute' (Buck n.d.). ${ }^{8}$

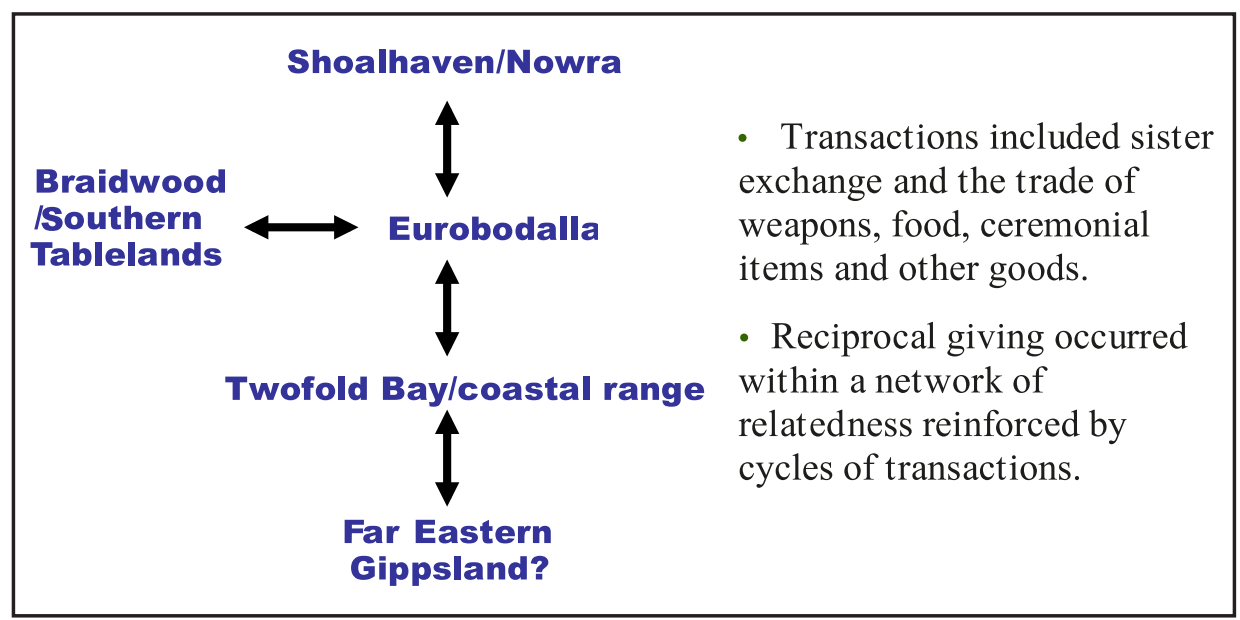

Figure 2.1 Howitt's (1904) evidence of Yuin exchange practices

Source: Boundaries of intermarriage and trade networks from Howitt (1904).

Broulee was also a hub for the distribution of blankets during a period in which the Aboriginal population was in rapid decline - most likely due to an influenza epidemic (Wesson 2000:130). Both Francis Flanagan and Captain Oldrey were

\footnotetext{
7 Robinson's journals push this southern boundary further to describe customary journeys to far east Gippsland (Robinson 1844).

8 It is evident that patron-client relations developed between Hawdon and several Aboriginal people who returned seasonally to work for him over a number of years. Aboriginal people were motivated to work for the settlers on a seasonal basis, preferring to wander off in the warmer months when resources were plentiful along the coast.
} 
responsible for distributing blankets and providing a census of the number of Aboriginal people in the district. As Wesson (2000:131) identified, Oldrey's 1842 census was unusual because it included 'family groups and the names and ages of all members of a family'. Oldrey also detailed the country in which each family usually camped, with the greatest number of families clustered around the settlement at Broulee (Oldrey 1842). The comprehensive detail in Oldrey's blanket returns entails an intimate knowledge of the individual family groups that could have been achieved only through close relationships extending over a number of years. In contrast, Morris's census provided only the number of people to which blankets were distributed and the names of the adult male family members (Wesson 2000:131). Through the provisioning of blankets and establishing close relationships with Aboriginal people in the area, Oldrey (along with Hawdon) can be credited with narrowing the social and spatial distances between Aboriginal people and the broader community of settlers at Broulee. In the absence of kin terms being used for individual settlers, however, it is impossible to argue that this relatedness was extended to kin relations in the manner in which Redmond describes the relationship between Ngarinyin workers and white stock owners in the Kimberley, where 'relative strangers' became 'strange relatives' (Redmond 2005:234).

Understanding the rescue of the survivors of the Rover in terms of relations of obligation based on relatedness is also instructive in this respect. I suggest that the rescue was a projection of relations of obligation onto the strangers in the boat, who were probably thought to be part of the local settler community. Oldrey petitioned the colonial administration to provide a reward for the heroes involved but his requests were refused. Taking the matter into his own hands, Oldrey had several brass gorgets fabricated for the rescuers. Oldrey is also credited as 'pleading the cause' of an Aboriginal man held in captivity at the police office (Townsend, cited in Cleary 1993:39). Once again, Oldrey was involved in maintaining relatedness through exchange. In 'sticking up' for the man in captivity, the object of exchange exists as much in the material form of gorgets as it does in providing a service of the type that Keen describes as creating 'a more diffuse obligation'. Keen adds that the effects of a service on a relationship could be enduring, depending on the perceived value of the action' (Keen 2004:354). These 'gifts of service' are also reminiscent of Sansom's four orders of 'signal service' in which 'bailing out' — or acts of rescue - 'transforms the relationship between heroic rescuer and saved victim for as long as they both shall live' (Sansom 1988:169). 


\section{Provisioning of Strangers?}

Sansom's schema is problematic if we return to the provisioning of Clarke's party in 1797, keeping in mind they were probably the very first Europeans any of the people at the Tuross camp had met. Stumbling out of the bush, starved and dishevelled, they must have had curiously white skin. Did they resemble a Tulungul, the spirit or ghost of a dead relative described by Howitt (1904:463)? Why would gift giving be triggered with absolute strangers? This is a puzzle for which I have no definitive answers. I suspect that it had something to do with a belief that Clarke and his men were physical manifestations of supra-natural beings; or, as evidence that information about the colony in Sydney had spread to the South Coast via the 'bush telegraph'; or, with a more generalised (or perhaps even locally defined) predisposition towards generosity as Les Hiatt's 'highest secular value' in Aboriginal Australia (Hiatt 1982:14).

The first rationale (based on misunderstanding) is certainly not without its problems. Sahlin's (1995) view that Hawaiians perceived Captain Cook as a physical manifestation of the god Lono has been greatly disputed (see Borofsky 1997 for a review of the debate). William Buckley's experience in Victoria, however, lends some credibility to this premise. In Morgan's account collected in 1852, Buckley stated that the Wautharong people thought he was the returned spirit of a dead relative and gave him the name Murrangurk, 'meaning literally, returned from the dead' (Flannery and Morgan 2002:45).

They called me Murrangurk, which I afterwards learnt, was the name of a man formerly belonging to their tribe, who had been buried at the spot where I had found the piece of spear I still carried with me. They have a belief, that when they die, they go to some place or other, and are there made white men, and that they then return to this world again for another existence. They think all the white people previous to death were belonging to their own tribes, thus returned to life in a different colour. (Flannery and Morgan 2002:38-9)

Based on this section of Buckley's account, it seems that the incorporation of Buckley into the Wautharong 'tribe' was more of a case of 'reincorporation' based on reincarnation beliefs. Prior to being given the name Murrangurk, however, Buckley had been provided with seafood on his initial encounter with Wautharong men in which he feared that he was going to be cannibalised: 'At length my suspense ended, by their taking the fish, fairly dividing them, and handing to me the first and best portion' (Flannery and Morgan 2002:31). In view of the available evidence, it appears that provisioning preceded the reincorporation of the dead relative's spirit (manifested in the white skin of William Buckley) into the Wautharong network of kin relations. 
The second rationale assumes that information about the presence and activities of Europeans had spread south from Sydney in the nine years between 1788 and 1797. It is possible that the 'bush telegraph' had conveyed news about both the wealth of new and desirable goods at the colony and the violence and terrifying new technologies. In the Townsville region of northern Queensland, James Morrill's account gives precedence to this rationale, as information was systematically spread about the presence of the white people who had come from the sea:

When they had done, they came and fetched us into their midst as on the previous evening, to show us to them. This was continued evening after evening for about six or eight evenings successively, as representatives from the more distant tribes came in to see the wonderful people, til the most distant known to them had seen us. (Morrill 2006:33)

Later, Morrill's party was again exhibited to a much larger gathering, involving up to 1000 representatives of 10 'tribes'. ${ }^{9}$ In the case of the NSW South Coast, the existence and efficacy of a 'bush telegraph' hinge on questions of communicability - whether Yuin networks of relatedness extended north towards Sydney and if there was some overlap between the language groups in these regions.

Howitt's observations of the Bunan male initiation ceremonies involved groups from as far north as the Shoalhaven and west to the Braidwood district, and it is likely that these gatherings involved the exchange of information about the settlers (Howitt 1904:519-20). ${ }^{10}$ This question also relies on shared languages or bilingualism in the regions between the Eurobodalla and Tharawal-speaking groups near Botany Bay. In her analysis of language ranges in south-eastern New South Wales, Wesson suggests that people in the Ulladulla region were 'bilingual, that both Thoorga and Tharawal were typically spoken in the region, or that an indeterminate form of the two languages was in use in the area' (Wesson 2000:157). Based on the evidence of communicability, it is therefore possible that information about the Europeans had been circulated between groups as far south as the Tuross River by 1797. Yet two questions remain that are impossible to answer with any degree of certainty: did reports of violent new technologies outweigh the allure of desirable goods? And, should encounters with Europeans be feared or welcomed with the anticipation of reciprocity?

Expanding on the third rationale, it seems that the idea of relatedness being prior to, or essential for, exchange could be inverted so that exchange itself facilitates relatedness. In any case, it is the predisposition towards exchange (as

9 The evidence suggests that this gathering was a male initiation ceremony.

10 Reynolds suggested that news about Europeans was spread rapidly throughout Australia along 'traditional trade routes' (Reynolds 1981:11). 
a function of maintaining relatedness) that was characteristic of the nonviolent interactions between Aboriginal people and the first wave of settlers on the NSW South Coast. It is this predisposition that also led to the amelioration of conflict, as a cycle of theft and reprisals, and the rapid incorporation of Aboriginal labour to fill the critical labour shortage in the primary-sector industries; however, I do not want to overstate relatedness in terms of the social incorporation of Aboriginal people into settler society. Indeed, increases in the scale of settlement were concomitant with the increasing marginalisation of Aboriginal people from town life. Racial attitudes were reinforced by government policies and rhetoric designed to segregate and exclude Aboriginal people from interacting with settler society. Accounts of the subsequent years bemoan Aboriginal people 'begging' around the coastal towns during periods when work was scant and the fish were off the bite. I suggest that a more accurate reflection on this period would view these actions as evidence that the settlers had become incorporated into the Indigenous social and economic worlds of mutual obligation, and demand-sharing expectations had been extended, through relatedness, onto relative strangers (Peterson 1993). ${ }^{11}$

\section{Conclusion}

A final point that I want to emphasise is that the early colonial history of the Eurobodalla points to a highly localised and specific experience of colonialism. Through the course of my examination of the maritime frontier, I have argued that the pervasiveness of violence and terror as a self-reproducing social fact correlates well with Taussig's (1987) notion of a 'culture of terror'. Yet, despite what appears to have been a unified colonial mind-set, several individuals (including the missionary Harper, Captain William Oldrey and John Hawdon) showed some openness to Indigenous difference and socio-cultural complexity and, in doing so, facilitated the incorporation of settlers into Indigenous relations of obligation. It is always tempting to view colonialism as a totalising, monolithic process accompanied by a unified discourse; however, I agree with Nicholas Thomas's suggestion that 'only localised theories and historically specific accounts can provide much insight into the varied articulations of colonizing and counter-colonial representations and practices' (Thomas 1994:ix). Colonialism (in much the same way as 'frontier') unfurls itself in a variety of places and times, economic circumstances and modes of production. Yet it also encompasses myriad individual-level predilections, epistemes and

\footnotetext{
11 Both Reynolds (1981) and Broome (1982) briefly allude to the notion that begging (as an emergent practice) was related to Indigenous domestic moral and economic systems, although neither author provides a theoretical elaboration of that relationship. While I also suggest here the possibility of a link in certain contexts, a detailed discussion of evidentiary and theoretical perspectives is necessary and is beyond the scope of this chapter.
} 
interactions. Despite mythologised characterisations of South Coast Aboriginal people as 'cannibalistic savages', the racialised and terrified subjectivities that were generated in the convict context were not always projected onto relations with the Indigenous 'other'. Indeed, by resisting claims on their subjectivities by the notion that colonialism inexorably consists of perilous and luridly violent encounters, some individuals were able to find a measure of redemption outside the colonial imaginary.

\section{Acknowledgments}

This chapter owes a special debt to Ian Keen, Nic Peterson and Tony Redmond for their constructive feedback. I would also like to acknowledge and express my gratitude to Philip Taylor for his incisive thoughts and comments on an earlier version of this chapter.

\section{References}

Altman, J. 2001. Sustainable Development Options on Aboriginal Land: The hybrid economy in the twenty-first century. Canberra: Centre for Aboriginal Economic Policy Research, Australian National University.

Amery, R. and Muhlhausler, P. 1996. Pidgin English in New South Wales. In P. Muhlhausler, D. Tryon and S. Wurm (eds), Atlas of Languages of Intercultural Communication in the Pacific, Asia, and the Americas. Berlin: Mouton de Gruyter.

Becke, L. and Jeffery, W. 1896. A First Fleet Family: A hitherto unpublished narrative of certain remarkable adventures compiled from the papers of Sargeant W. Dew of the marines. London: T. Fisher Unwin.

Bhabha, H. 1993. The Location of Culture. New York: Routledge.

Biber, K. 2005. Cannibals and colonialism. Sydney Law Review 27: 623-37.

Bonnemère, P. and Lemonnier, P. 2009. A measure of violence: forty years of 'first contact' among the Ankave-Anga (Papua New Guinea). In M. Jolly, S. Tcherkézoff and D. Tryon (eds), Oceanic Encounters: Exchange, desire, violence. Canberra: ANU E Press.

Borofsky, R. 1997. Cook, Lono, Obeyeskere and Sahlins. Current Anthropology 38: 255-65. 
Indigenous Participation in Australian Economies II

Bowden, K. 1952. George Bass 1771-1803: His discoveries, romantic life and tragic disappearance. Melbourne: Oxford University Press.

Broome, R. 1982. Aboriginal Australians: Black Response to White Dominance, 1788-1980. Sydney: George Allen and Unwin.

Buck, M. n.d. Old Colony Days: John Hawdon's letters. Volume II. Moruya, NSW: Moruya and District Historical Society.

Cleary, T. 1993. Poignant Regalia: 19th century Aboriginal breastplates \& images. Sydney: Historic Houses Trust of New South Wales.

Darling, G. 1827. Governor Darling to Earl Bathurst, despatch no. 32. Historic Records of Australia XIII (1).

Dowd, B. 1972. Thomas Florance, 1783-1867. Journal of the Royal Australian Historical Society 58: 89-100.

Fanon, F. 1970. Black Skin, White Masks. St Albans, UK: Paladin.

Flanagan, F. 1845. Response to circular letter from Francis Flanagan. In Report from the Select Committee on the Condition of the Aborigines with Appendix, Minutes of Evidence and Replies to a Circular Letter. Sydney: Government Printing Office.

Flannery, T. E. and Morgan, J. 2002. The Life and Adventures of William Buckley; 32 years a wanderer amongst the Aborigines of the then unexplored country around Port Phillip, now the Province of Victoria. Melbourne: Text Publishing.

Gibbney, H. J. 1989. Eurobodalla: History of the Moruya district. Sydney: in association with the Shire of Eurobodalla.

Goulding, M. and Waters, K. 2005. Eurobodalla Aboriginal Cultural Heritage Study South Coast New South Wales. Carlton North, Vic.: Goulding Heritage Consulting Pty Ltd.

Harper, J. 1826. Mr. Harper's Journal [October 1826]. Wesleyan Mission House Despatches, Bonwick Transcripts Missionary, 1824-1829, Mitchell Library, Sydney.

Harper, J. 1827. Harper to Rev. J. Newstead, 25 April 1827. In Wesleyan Mission House Despatches, Bonwick Transcripts Missionary, 1824-1829, Mitchell Library, Sydney.Henley, K. and Plomley, B. 1990. The Sealers of Bass Strait and the Cape Barren Island Community. Hobart: Blubber Head Press. 
Hiatt, L. 1982. Traditional attitudes to land resources. In R. M. Berndt (ed.), Aboriginal Sites, Rites and Resource Development. Perth: University of Western Australia Press.

Howitt, A. W. 1904. The Native Tribes of South-East Australia. London: Macmillan.

James, A. 2001. Batemans Bay: Story of a town. Batemans Bay, NSW: Selfpublished.

Johnson, R. 1821. Report from Robert Johnson, 10th December 1821. Sydney Gazette.

Jolly, M., Tcherkézoff, S. and Tryon, D. (eds) 2009. Oceanic Encounters: Exchange, desire, violence. Canberra: ANU E Press.

Keen, I. 2004. Aboriginal Economy and Society: Australia at the threshold of colonisation. South Melbourne: Oxford University Press.

Keen, I. 2010. Introduction. In I. Keen (ed.), Indigenous Participation in Australian Economies: Historical and anthropological perspectives. Canberra: ANU E Press.

Lindenbaum, S. 2004. Thinking about Cannibalism. Annual review of Anthropology 33: 475-98.

Loos, N. 1982. Invasion and Resistance: Aboriginal-European relations on the north Queensland frontier 1861-1897. Canberra: Australian National University Press.

Maclehose, J. 1838. Picture of Sydney and Stranger's Guide in New South Wales for 1838. Sydney: J. Spilsbury.

Mackaness, G. (ed.) 1978. George Augustus Robinson's Journey into South-Eastern Australia, 1844. Australian Historical Monographs 19 [NS]. Dubbo, NSW: Review Publications.

Morrill, J. 2006. 17 Years Wandering Among the Aboriginals. (Originally published 1864, with photographs published by Eric Mjoberg, 1918). Australian Aboriginal culture series 1. Virginia, N.T.: Welch.

Myers, F. 1986. Reflections on a meeting: structure, language, and the polity in a small-scale society. American Ethnologist 13 (3): 430-47.

Oldrey, W. 1842. Return of Aboriginal Natives taken at Broulee the 6th day of May 1842. Colonial Secretary Special Bundles: Aborigines 1837-44: Papers dealing with the issue of blankets, and including returns of the native population in the various districts, State Records of New South Wales, Sydney. 
Indigenous Participation in Australian Economies II

Organ, M. 1990. A Documentary History of the Illawarra and South Coast Aborigines. Wollongong, NSW: Aboriginal Education Unit, Wollongong University.

Perry, T. M. 1963. Australia's First Frontier: The spread of settlement in New South Wales 1788-1829. Melbourne: Melbourne University Press in association with The Australian National University.

Peterson, N. 1993. Demand sharing: reciprocity and the pressure for generosity among foragers. American Anthropologist 95: 860.

Pickering, M. 1999. Consuming doubts: what some people ate? Or what some people swallowed? In L. Goldman (ed.), The Anthropology of Cannibalism. Westport, Conn.: Bergin \& Garvey.

Redmond, A. 2005. Strange relatives: mutualities and dependencies between Aborigines and pastoralists in the northern Kimberley. Oceania 75: 234-46.

Reece, R. 1974. Aborigines and Colonists. Sydney: Sydney University Press.

Reynolds, H. 1981. The Other Side of the Frontier: An interpretation of the Aboriginal response to the invasion and settlement of Australia. Townsville, Qld: History Department, James Cook University.

Robinson, F. and York, B. 1977. The Black Resistance. Camberwell, Vic.: Widescope International Publishers.

Robinson, G. A. 1844. Field journals April 13 - May 11 1844. Unpublished transcription by I. D. Clark [1998], Mitchell Library, Sydney.

Rose, C. 1923. Recollections of the early days of Moruya. Journal and Proceedings of the Royal Australian Historical Society VIII.

Sahlins, M. 1995. How 'Natives' Think. About Captain Cook, for example. Chicago: University of Chicago Press.

Sansom, B. 1988. A grammar of exchange. In I. Keen (ed.), Being Black: Aboriginal cultures in 'settled' Australia. Canberra: Aboriginal Studies Press.

Strathern, M. 1992. The decomposition of an event. Cultural Anthropology 7: 244-54.

Taussig, M. 1987. Shamanism, Colonialism and the Wild Man. Chicago: University of Chicago Press.

Taussig, M. 2002. Culture of terror - space of death: Roger Casement's Putumayo Report and the explanation of torture. In J. Vincent (ed.), The Anthropology of Politics. A reader in ethnography, theory and critique. Oxford: Blackwell. 
Thomas, N. 1994. Colonialism's Culture: Anthropology, travel and government. Cambridge: Polity Press.

Walker, W. 1821. Walker to Watson, 8 November 1821. Wesleyan Mission House Despatches, Bonwick Transcripts Missionary, 1824-1829, Mitchell Library, Sydney.

Walker, W. n.d. Walker to General Secretaries. Wesleyan Mission House Despatches, Bonwick Transcripts Missionary, 1824-1829, Mitchell Library, Sydney.

Wesson, S. 2000. An Historical Atlas of the Aborigines of Eastern Victoria and Far South-Eastern New South Wales. Melbourne: School of Geography and Environmental Science, Monash University.

Wesson, S. 2002. The Aborigines of eastern Victoria and far south-eastern New South Wales, 1830 to 1910: an historical geography. Unpublished PhD thesis, School of Geography and Environmental Science, Monash University, Melbourne.

White, J. M. 2010. Peas, beans and riverbanks: seasonal picking and dependence in the Tuross Valley. In I. Keen (ed.), Indigenous Participation in Australian Economies: Historical and anthropological perspectives. Canberra: ANU E Press.

White, J. M. 2011. Histories of Indigenous-settler relations: reflections on internal colonialism and the hybrid economy. Australian Aboriginal Studies 1: 81-96. 